\title{
Rytuały pogrzebowe w pamięci mieszkańców obszarów wiejskich Dolnego śląska
}

\author{
WPROWADZENIE
}

Współcześnie znacząco zmienia się sfera związana z umieraniem i śmiercią, co powoduje, że znikają one z życia publicznego, często stając się tematem zakazanym. Jednocześnie od lat dziewięćdziesiątych mamy do czynienia z rozwojem socjologii umierania, śmierci i żałoby, zwanej inaczej tanatosocjologią. Wątki dotyczące umierania i śmierci są obecne w dziełach Jana Szczepańskiego, wyczerpującego ich przeglądu dokonał Janusz Mariański ${ }^{1}$.

W artykule tym zamierzam przedstawić zmiany, jakie zaszły w rytuałach pogrzebowych w opiniach dwóch pokoleń mieszkańców wsi dolnośląskiej. Badania zostały przeprowadzone w czerwcu i lipcu 2017 r., w ramach ćwiczeń terenowych organizowanych dla studentów Instytutu Socjologii Uniwersytetu Wrocławskiego. Zrealizowano sto wywiadów swobodnych z listą poszukiwanych zagadnień w dwóch grupach wiekowych. Pierwszą grupę stanowili respondenci starsi, tzn. po 65. roku życia. Często pamiętają oni jeszcze czasy, kiedy nie mieszkali na Dolnym Śląsku. Drugą grupą były osoby poniżej 35. roku życia. W większości wywiadów udało się zachować pokrewieństwo badanych, tzn. przeprowadzono wywiady np. z babcią i wnuczką. Dzięki takiemu doborowi respondentów podjęta została próba pokazania zmian, jakie dokonały się w tym zakresie w ciągu ostatnich kilkudziesięciu lat na obszarach wiejskich. W badaniu wzięły udział 74 kobiety i 26 mężczyzn, najmłodsza respondentka miała 18 lat, najstarsza 84 .

Badania zostały przeprowadzone metodą jakościową. Techniką badawczą zastosowaną w celu zebrania informacji był wywiad ze standaryzowaną listą pytań, natomiast narzędziem badawczym był samodzielnie skonstruowany kwestionariusz wywiadu

J. Mariański, Śmierć i umieranie w ujęciu socjologicznym w nawiązaniu do myśli Jana Szczepańskiego, [w:] W kręgu myśli Profesora Jana Szczepańskiego, t. 3, red. D. Kadłubiec, E. Ogrodzka-Mazur, A. Kasperek, Wydawnictwo ARKA, Cieszyn 2017, s. $21-40$. 
o mniejszym stopniu standaryzacji ${ }^{2}$. Przeprowadzone wywiady miały na celu skłonienie rozmówcy do zastosowania jego własnych pojęć, ujęcie tych pojęć w ich kontekście, rozszerzenie lub skracanie odpowiedzi na pewne pytania ${ }^{3}$. Zastosowanie opisanej techniki pozwala na uniknięcie schematyzacji i narzucania badanym odpowiedzi. Technika okazała się trafna, szczególnie w rozmowach z najstarszymi respondentami.

Kolejne zagadnienia w wywiadzie dotyczyły: samego momentu śmierci, sposobów zawiadamiania wsi, rodziny, znajomych o śmierci, przygotowania zmarłego do pochówku, czuwania przy zmarłym i zwyczajów związanych z wyniesieniem zmarłego, wyposażaniem zmarłych, zwyczajów związanych z wyprowadzaniem zwłok z domu do kościoła, wynoszeniem trumny i transportem zmarłego na cmentarz, samego przebiegu pogrzebu, poczęstunku po pogrzebie, żałoby. W badaniu proszono o przedstawienie własnych doświadczeń.

Można wskazać kilka powodów, dla których warto realizować takie badania. Po drugiej wojnie światowej niemal cała ludność Dolnego Śląska uległa wymianie. Region został zasiedlony przez przybyszów z różnych rejonów Polski i Europy (m.in. kresowiacy, przybysze z ziemi kieleckiej, rzeszowskiej, Mazowsza, Polesia, liczne grupy stanowią też reemigranci z Bośni, Górale Czadeccy z Rumuni oraz Łemkowie).

Kolejnym argumentem na rzecz wyboru Dolnego Śląska jest jego silne zurbanizowanie. Bliskość miast, dostęp do edukacji, możliwość znalezienia pracy są istotnymi elementami wpływającymi na rozwój obszarów wiejskich. Ze względu na niedużą odległość od miasta wojewódzkiego oraz innych miast można zakładać, że zmiany we wzorach i praktykach dotyczących organizacji rytuałów pogrzebowych następują szybciej niż dzieje się to na obszarach wiejskich w innych regionach Polski (lub położonych bardziej peryferyjnie). Jak wynika z badań, wyższym poziomem rozwoju społeczno-gospodarczego odznaczają się gminy wiejskie położone w zachodniej części kraju w stosunku do tych z jego wschodniej części ${ }^{4}$. Z drugiej strony w omawianym województwie występuje wszystkie sześć typów gmin wiejskich wyróżnionych przez M. Stanny, tzn.

1) z dominacją rolnictwa indywidualnego,

2) z dominacją rolnictwa wielkoobszarowego,

2 I. Przybyłowska, Wywiad swobodny ze standaryzowana lista poszukiwanych informacji i możliwości jego zastosowania w badaniach socjologicznych, „Przegląd Socjologiczny” 1978, t. 20, s. 63.

3 I. Helling, Metoda badań biograficznych, [w:] Metoda biograficzna w socjologii, red. J. Włodarek, M. Ziółkowski, PWN, Warszawa 1990, s. 23.

$4 \quad$ M. Stanny, Przestrzenne zróżnicowanie rozwoju obszarów wiejskich w Polsce, IRWiR PAN, Warszawa 2013, s. 176. 
3) typ pośredni z przewagą funkcji rolniczej,

4) typ gmin wielodochodowego, rozdrobnionego rolnictwa,

5) typ wielofunkcyjny, zrównoważonego sektora rolnego i pozarolniczego,

6) gminy silnie zurbanizowane ${ }^{5}$.

Region jest więc wewnętrznie zróżnicowany, jeśli chodzi o warunki funkcjonowania i rozwoju.

Dobór próby był nielosowy, zastosowano tzw. metodę kuli śnieżnej. W zamierzeniu miały to być osoby, które będą posiadały pogłębioną wiedzę na temat zwyczajów towarzyszących pogrzebowi oraz funkcjonowaniu cmentarzy. Wywiady przeprowadzono w następujących gminach: Grębocice, Jeżów Sudecki, Kłodzko, Kostomłoty, Kąty Wrocławskie, Siechnice, Stoszowice, Świdnica, Wrocław. Ze względu na ograniczone możliwości finansowe badaniami nie zostało objęte całe województwo.

\section{O RYTUAŁACH PRZEJŚCIA}

Analizując dzieła socjologów i antropologów dotyczące rytuałów, można zauważyć, że każdy rytuał odgrywa ważną rolę w życiu człowieka, niezależnie od tego, w jakim społeczeństwie czy kulturze człowiek ten funkcjonuje. F. Znaniecki pisał, „każdy tradycyjny rodzaj stosunków społecznych posiada swój rytuał”. Rytualne schematy istnieją zawsze i są rozpoznawalne niezależnie od typów kultury. Stanowią swoistą metanarrację, dzięki czemu pozwalają nie tylko na odczytywanie społecznych doświadczeń, ale również na ich powtórne przeżywanie w interpretacyjnym odtwarzaniu ${ }^{7}$.

Rytuały dają ludziom oparcie psychiczne i społeczne, zaspokajają potrzebę współuczestnictwa w życiu społecznym, komunikują „stałe”, ważne treści dla grupy ${ }^{8}$. Równocześnie odpowiadają na społeczne potrzeby ujmowania afirmowanych przez grupę wzorów i wartości w swego rodzaju rygory i nakazy, służą wprowadzaniu jednostki w kulturę9. Są więc rytuały ważnym narzędziem socjalizacji.

Tamże, s. 201-207.

6 F. Znaniecki, Socjologia wychowania. Urabianie osoby wychowanka, t. 2, Naukowe Towarzystwo Pedagogiczne, Lwów 1930, s. 284.

7 W. J. Burszta, Antropologia kultury. Tematy, teorie, interpretacje, Wydawnictwo Zysk i S-ka, Poznań 1998, s. $100-111$.

8 K. Żygulski, Przemiany obyczajowe a kultura masowa, [w:] Nowe obyczaje i obrzędy, red. E. Ciupak, M. Czerwiński, J. K. Makulski, K. Żygulski, Młodzieżowa Agencja Wydawnicza, Warszawa 1977, s. 23.

9 J. Szczepański, Elementarne pojęcia socjologii, PWN, Warszawa 1970, s. 93. 
Analizując, czym jest rytuał, nie można zapominać, że funkcjonuje on w odmiennych kontekstach społecznych. Wymienia się wiele rodzajów rytuałów, m.in. religijne, estetyczne, cywilne, związane z cyklami rodzinnych uroczystości, narodzinami, osiągnięciem pełnoletności czy śmiercią ${ }^{10}$. Rytuały mogą odgrywać rolę skutecznych narzędzi uprawomocniania i podtrzymywania uniwersum symbolicznego i kulturowego danej grupy ${ }^{11}$. Należy jednak pamiętać, że działo się tak zwłaszcza w tzw. społeczeństwach tradycyjnych. Klasyk socjologii E. Durkheim definiował rytuały jako „fundamentalne składniki istnienia wierzeń i systemów religijnych"12. Analizując społeczeństwo współczesne, Józef Baniak pisze:

rytuał jako zjawisko lub fakt społeczno-kulturowy, w tym religijny, nie zaginął w społeczeństwie miejskim i przemysłowym, nie mówiąc już o jego roli w życiu środowiska wiejskiego. Badania wykazały, że jedynie zmienia on swoje formy wyrazu, ekspresji zewnętrznej, a często występuje w postaci pierwotnej. Nie można więc uznać za prawdziwą tezy, która sugeruje, że rytuał religijny stanowi wyłącznie cechę społeczeństwa tradycyjnego ${ }^{13}$.

Twórcy teorii rytuałów przejścia, A. van Gennepowi, udało się stworzyć narzędzie, dzięki któremu ujmuje się w kategorie, wyjaśnia i interpretuje wiele zachowań społecznych. Według van Gennepa każdy z rytuałów przejścia składa się z trzech zasadniczych faz: wyłączania, marginesu i włączania ${ }^{14}$. O ile faza pierwsza (separacji) i ostatnia (agregacji) mają duże znaczenie dla struktury społecznej (angażują nie tylko uczestników rytuału, ale większość społeczności), o tyle faza środkowa jest najdłuższym i zasadniczym elementem rytuałów przejścia, stanowi również o specyfice i oryginalności tej grupy rytuałów ${ }^{15}$.

\section{FUNKCJE POGRZEBÓW}

Najprostsza definicja pogrzebu mówi, że to „nazwa zespołu czynności kulturowo-religijno-kultowo-rytualnych towarzyszących pogrzebaniu ciała zmarłego"16. Z socjologicznego punktu widzenia pogrzeb to pewien wzór kulturowy, na który składa się

10 J. Baniak, Istota, funkcje i ewolucja rytuału religijnego, „Studia Socjologiczne” 1992, nr 1, s. 97.

11 P. L. Berger, T. Luckmann, Społeczne tworzenie rzeczywistości, tłum. J. Niżnik, PIW, Warszawa 1983, s. 160-161.

12 E. Durkheim, Elementarne formy życia religijnego. System totemiczny w Australii, tłum. A. Zadrożyńska, PWN, Warszawa 1990, s. 4.

13 J. Baniak, Istota, funkcje..., s. 111.

14 L. Stomma, Antropologia kultury w Polsce - dziedzictwo, pojęcia, inspiracje, materiały do słownika, cz. III, „Polska Sztuka Ludowa" 1981, R. 35, nr 1, s. 59-60.

15 Tamże, s. 60.

16 M. Wańczowski, Księga żałoby i śmierci, nakł. autora, Opole 1993, s. 258. 
w miarę trwały i spójny zestaw ról obłożonych sankcjami - wewnętrzną i zewnętrzną. Wzory zachowań w przypadku rytuałów mają niewielki margines swobody, obowiązują one w szczególności rodzinę zmarłego, sąsiadów, członków społeczności, a także księdza jako osobę, która przeprowadza liturgię pogrzebu.

Ceremonie pogrzebowe pełnią wiele funkcji przekraczających znacznie potrzebę pogrzebania ciała. Próbując uporządkować funkcje spełniane przez ceremonie pogrzebowe, A. Ostrowska posłużyła się rozróżnieniem na funkcje jawne i ukryte. Rozróżnienie takie pozwala „na oddzielenie subiektywnych celów od funkcjonalnych rezultatów działania, ponadto przypomina, że postępowanie może spełniać jakąś funkcję dla grupy, choć może ono być bardzo odległe od oficjalnego celu"17. Pogrzeby są więc również źródłem wartości i korzyści osiąganych przez uczestników rytuału. Korzyści mogą być indywidualne (np. pomoc dla rodziny pogrążonej w żałobie) lub społeczne (wzmocnienie tożsamości grupowej poprzez uczestnictwo w zbiorowej ekspresji uczuć).

Cztery podstawowe funkcje pogrzebów to: funkcja higieniczno-sanitarna, ułatwiająca "przejście” (związane z wiarą w zmianę formy egzystencji) oraz terapeutyczna - funkcje nakierowane na najbliższe otoczenie, a także społeczna - nakierowana na całą społeczność ${ }^{18}$. Funkcje jawne nakierowane są na zmarłego, jednak pogrzeb poprzez funkcje ukryte przynosi korzyści żywym:

- Uczestnictwo w rytuałach pogrzebu potwierdza realność śmierci.

- Pogrzeb stanowi naturalną scenerię dla wyrażenia uczuć związanych ze śmiercią. Osoby zdolne do okazywania emocji mogą w czasie pogrzebu rozładować wiele uczuć (np. płacz) w atmosferze społecznego zrozumienia.

- Odpowiednio przygotowana i przeprowadzona ceremonia odgrywa rolę symbolu statusu zmarłego i jego rodziny.

- Sam pogrzeb rozpoczyna proces reintegracji osób w żałobie ze społecznością, niejednokrotnie w nowej roli, zmienionej na skutek odejścia zmarłego. Rodzina i przyjaciele udzielają zapewnienia o pomocy i poparciu w zmienionej sytuacji życiowej.

\footnotetext{
A. Ostrowska, Śmierć w doświadczeniu jednostki i społeczeństwa, Wyd. IFiS PAN, Warszawa 2005, s. 235.

18 Tamże, s. 236.
} 
- Pogrzeby integrują uczestników (społeczność) dając okazję do spotkania, odnowienia kontaktów, kształtowania zbiorowej pamięci.

- Wiadomość o śmierci, a następnie uczestnictwo w pogrzebie stymulują uczestników do konfrontacji z własną śmiertelnością, zmuszają do refleksji na temat wartości związanych w danej kulturze z życiem i śmiercią.

- Pogrzeby to także potwierdzenie istniejącego porządku społecznego. Pomimo śmierci jednostki i nawet największego żalu z nią związanego, życie toczy się dalej, porządek społeczny zostaje zachowany ${ }^{19}$.

We wszystkich kulturach tradycyjne pogrzeby, a także przygotowania przedśmiertne, są nastawione nie tylko na potrzeby umierającego czy już zmarłego, ale zawierają przede wszystkim treści ważne dla żywych.

\title{
ŚMIERĆ I POGRZEBY W SPOŁECZNOŚCIACH WIEJSKICH W PAMIĘCI BADANYCH
}

\begin{abstract}
Nie zrozumiemy sensu życia, póki z całą jasnością nie uświadomimy sobie, że jego kresem i celem jest śmierć. [...] Od dzieciństwa wzrastamy w lęku przed śmiercią [...] doświadczamy reakcji innych na śmierć, a ta jest zawsze rozpaczą, smutkiem, płaczem [...] Dopiero znacznie później uświadamiamy sobie, że nad trumną czy grobem rzadko płaczemy nad zmarłym, a płaczemy nad sobą i nad wyobrażeniem własnej śmierci, którą identyfikujemy z klęską ostateczną ${ }^{20}$.
\end{abstract}

Słowa Jana Szczepańskiego są dobrym wstępem do rozważań na temat śmierci i pogrzebów w doświadczeniach badanych mieszkańców obszarów wiejskich. Przeprowadzone wywiady pokazują subiektywny obraz tych zjawisk, tak jak były one postrzegane i doświadczane przez badanych, którzy byli w nie uwikłani.

Śmierć w polskiej tradycji ludowej najczęściej przedstawiano pod postacią antropomorficzną, przy czym mogła występować zarówno z wyraźnie „ludzkim obliczem”, jak również jako rozkładający się trup lub szkielet $\mathrm{z}$ atrybutami przemijalności i bez-

19 Tamże, s. 246.

20 J. Szczepański, Sprawy ludzkie, Czytelnik, Warszawa 1980, s. 296-297. 
względności ${ }^{21}$. Śmierć w tradycji utożsamiano z kościotrupem czy też z rozkładającymi się zwłokami. Bardzo często w wierzeniach ludowych śmierć przybierała także postać kobiety, nieraz starej nieznajomej, raczej o zwyczajnym wglądzie - jak każda „baba”22. Personifikacja śmierci, a nawet nadawanie jej zdrobniałych imion (np. Basia na Mazowszu i Podlasiu, Kasia w Wielkopolsce) pozwalało przynajmniej częściowo „oswoić” się z nią, zmniejszyć lęk przed nią.

W czasach młodości najstarszych respondentów (lata trzydzieste i czterdzieste), ludzie najczęściej umierali w domach. Obecnie najczęstszym miejscem, gdzie umiera człowiek, jest szpital. Śmierć nie jest już opisywana w kategoriach antropomorficznych, ale wydarzenia biologiczno-medycznego. Wspólnym stwierdzeniem pozostaje, że śmierć, podobnie jak życie, nie jest wyłączenie aktem indywidualnym. To ważny moment w cyklu życia jednostki, któremu towarzyszą rytuały, ceremonie, a ich celem, jak pisze P. Ariès, jest „wyrażenie solidarności jednostki z jej rodem i jej wspólnotą"23. Jednak widać zdecydowaną różnicę w opowieściach na temat tego, jak wyglądał i wygląda pogrzeb w przypadku społeczności wiejskich.

Śmierć w rodzinie, w sąsiedztwie, w społeczności wiejskiej, tak jak narodziny czy ślub, stanowiła doniosłe wydarzenie. Wokół śmierci narosły olbrzymie tradycje, obrzędowość o silnym zróżnicowaniu regionalnym. W społecznościach tradycyjnych grę między życiem i śmiercią chłop nieustannie obserwował w codziennych sytuacjach. Jednostkowy akt umierania był zjawiskiem oczywistym, w przeciwieństwie do groźby zagłady rodziny czy wsi.

Dość wysoka śmiertelność wśród dzieci była czymś naturalnym, podbudowanym wyobrażeniem religijnym, które dusze ochrzczonych, zmarłych malców umiejscawiało wysoko w niebie ${ }^{24}$. Śmierć gwałtowna, niespodziewana czy poniesiona daleko od rodzinnych stron była odbierana jako nieszczęście, które jednak nie zagrażało istnieniu rodziny.

Poczucie solidarności z przyrodą i z życiem we wszystkich jego przejawach było ważnym elementem chłopskiej wizji śmierci. Najlepszy literacki obraz tego zjawiska dał Władysław Reymont w opisie śmierci Boryny. Niepotrzebne niszczenie jakiegokolwiek życia

${ }_{21}$ F. Rosiński, Śmierć w polskiej tradycji ludowej, [w:] Problemy wspótczesnej tanatologii, red. J. Kolbuszewski, t. 3, Wrocławskie Towarzystwo Naukowe, Wrocław 1999, s. 208.

22 M. Jakitowicz, Ludowe opowieści o oszukanej śmierci jako symptom „oswajania” zjawiska, [w:] Problemy wspótczesnej tanatologii, red. J. Kolbuszewski, t. 1, Wrocławskie Towarzystwo Naukowe, Wrocław 1997, s. 433.

23 P. Ariès, Pięć wariacji na cztery tematy, tłum. S. Cichowicz, J. M. Godzimirski, [w:] Antropologia śmierci. Myśl francuska. Wybór S. Cichowicz, J. M. Godzimirski, PWN, Warszawa 1993, s. 286.

24 J. S. Bystroń, Dzieje obyczajów w dawnej Polsce, t. 2, PIW, Warszawa 1994, s. 143. 
było wartościowane negatywnie. Człowieka zabijającego zwierzę usprawiedliwiało się tylko wówczas, gdy służyło to zaspokojeniu jego naturalnych potrzeb. Każde nadmierne zabijanie, np. na zarobek, było traktowane jako zerwanie tej naturalnej solidarności.

Umierano zazwyczaj w domu, w otoczeniu rodziny i sąsiadów, co stanowiło czynnik więziotwórczy. Powszechnie uważano, że człowiek, który prowadził uczciwe życie, jeśli zaopatrzony był w sakramenty, ma lekką, dobrą śmierć. Mieszkańcy wsi szczególnie bali się śmierci w izolacji społecznej. Za uprzywilejowanych w obliczu śmierci uchodzili ci, którzy posiadali dzieci i liczną rodzinę (r. 11, r. 18, r. 37). Dawało to umierającemu poczucie dobrze spełnionego obowiązku, dobrze przeżytego życia, wiarę w przedłużenie własnej egzystencji poprzez dzieci, w kontynuację rodziny i gospodarstwa, a przede wszystkim pewność, że będzie miał kto pomodlić się za duszę zmarłego i zadbać o jego grób (r. 28, r. 39, r. 50).

Przy łożu konającego szczególnie modlono się do patronów dobrej śmierci - św. Barbary (r. 4, r. 41) i św. Józefa (r. 3, r. 17, r. 19), odmawiano różaniec, litanię za umierających, zapalano gromnicę. W opowieściach są fragmenty mówiące, że nie należało - mimo przeżywanego bólu - głośno lamentować, rozpaczać, by nie utrudniać umierającemu odejścia z tego świata (r. 15, r. 32, r. 43). Podobne informacje odnotowuje Krystyna Turek pisząc, że w dawnych wierzeniach ludowych „płacz i łzy stanowiły poważne obciążenie dla zmarłego" ${ }^{25}$. Franciszek Rosiński dodaje, że dość powszechne było przekonanie, że „niedawno zmarły może w jakiś sposób zasygnalizować swoim bliskim, znajdującym się nawet na innym kontynencie, swoje zejście”26.

Bardzo mocno w odpowiedziach najstarszych respondentów jest akcentowany lęk, który dotyczył przede wszystkim pośmiertnych losów duszy, a nie samego faktu śmierci. Wierzono realnie w istnienie sądu nad duszą, diabła i piekła (r. 11, r. 9, r. 37). Wraz z biegiem lat i utratą sił fizycznych w sposób naturalny „dojrzewano do śmierci” i w sytuacji dobrze przeżytego życia czekano na przejście po nagrodę w wieczności (r. 4).

Po stwierdzonym zgonie (np. za pomocą lusterka) podejmowano różne czynności, aby ułatwić duszy zmarłego przejście do wieczności, a zarazem zabezpieczyć pozostałych domowników przed niebezpieczeństwami, które mogły im grozić ze strony zmarłego. $\mathrm{Na}$ dolnośląskiej wsi, w latach siedemdziesiątych i osiemdziesiątych otwierano okna lub

25 K. Turek, Ludowe zwyczaje, obrzędy i pieśni pogrzebowe na Górnym Śląsku, Wyd. Uniwersytetu Śląskiego, Katowice 1993, s. 28.

26 F. Rosiński, Śmierć w polskiej tradycji ludowej..., s. 217. 
drzwi, by dusza zmarłego mogła swobodnie opuścić dom. Zatrzymywano wskazówki zegara, bo dla nieboszczyka skończył się czas, a rozpoczęła wieczność. Zasłaniano lustra, okna, a nawet szklane przedmioty z obawy, iż „jeśli wizerunek zmarłego odbije się w nich, tak ktoś z rodziny szybko umrze"27. Powszechnie zamykano nieboszczykowi oczy, co tłumaczono możliwością wypatrzenia kogoś przez niego i ściągnięcia jakiegoś nieszczęścia (r. 23). Rozchylone usta podwiązywano chustą, by „kogoś nie wywołał”28.

Po zgonie danej osoby, w miejscowościach gdzie był kościół, starano się, by zadzwoniono „dzwonem dla konających” trzy razy z krótkimi przerwami, by wszyscy, którzy usłyszą to dzwonienie, pomodlili się za zmarłego (r. 25, r. 9).

Nieboszczyka należało starannie umyć, uczesać, natomiast wodę po umyciu, której przypisywano specjalną, niebezpieczną moc, wylewano na drogę lub w miejsce nieurodzajne. Starano się zmarłego ubrać przed jego zesztywnieniem. Ubieranie zmarłej kobiety w części opowieści było zarezerwowane tylko dla kobiet (r. 13, r. 9).

Różne były tradycje dotyczące ubioru nieboszczka oraz przedmiotów, jakie się wkładało do trumny. F. Rosiński pisze, że w biednych wsiach „rodzina kupowała mu do trumny najtańsze, tandetne ubranie. Buty papierowe specjalnie wyrabiano dla biedoty”29. Z kolei na Śląsku ubierano zmarłego w najlepszy, odświętny strój odpowiedni do jego wieku i płci. Bardzo dbano o to, by zmarłego obuć w trzewiki, „gdyż wierzono, że nieboszczyk nie może wejść na boso do nieba" ${ }^{30}$. W przeprowadzonych rozmowach podkreśla się, że większość osób w wieku starszym podejmowało i nadal podejmuje szereg działań, aby się do śmierci przygotować. Przygotowanie odpowiedniego ubrania jest jednym z podstawowych zadań. Jedna respondentka nie kryła oburzenia, kiedy na jednym z ostatnich pogrzebów na jakim była, zobaczyła w trumnie swoją ciocię w swetrze. Po zakończeniu części religijnej, na stypie wyraziła swoje oburzenie i żal w rozmowie z dziećmi zmarłej (r. 41).

Dorosłym wkładano i nadal wkłada się do trumny książeczkę do nabożeństwa, krzyżyk, medalik, obrazki (r. 11, r. 15, r. 27, r. 48). Nieraz też dodaje się niektóre rzeczy osobiste, np. okulary, laskę, chusteczkę do nosa. Do prawej kieszeni ubrania lub do ręki wkładano drobną monetę na „ostatnią ofiarę”. Zmarłym dzieciom wkładano zabawki, koszulkę chrzcielną, obrazki ze świętymi.

\footnotetext{
27 Tamże, s. 218.

28 K. Turek, Ludowe zwyczaje, obrzędy..., s. 30.

29 F. Rosiński, Śmierć w polskiej tradycji ludowej..., s. 219.

$30 \quad$ K. Turek, Ludowe zwyczaje, obrzędy..., s. 30.
} 
Od momentu śmierci do dnia pogrzebu niezwykle ważne były odwiedziny zmarłego przez niemal całą społeczność lokalną. Starano się, aby najpóźniej na trzeci dzień od śmierci odbył się pogrzeb. W ciągu dnia na zmianę rodzina i sąsiedzi czuwali przy nieboszczyku, tak aby nigdy nie został on sam. Ludzie modlili się, śpiewali pieśni religijne, wspominali życie zmarłego, niekiedy spotkania takie trwały do późnych godzin nocnych i były zakrapiane alkoholem.

Baby więcej modliły się i śpiewały, a chłopy to tak siedzieli czasem i pierdoły opowiadali, a zdarzało się, że pili, ale nie wszędzie, nie wszystkich na to było stać. Chłopy przynosili między sobą. Jak sobie chcieli pogadać, to żeby im się lepiej gadało to sobie wypili. Na przykład mówili, czy to był dobry gospodarz, czy dobry sąsiad, czy skłonny był do pomocy, czy raczej sępił na wszystkim, czy miał ciężką rękę i czy jego babie to teraz będzie lżej, czy nie (r. 30).

Często zdarzało się tak, że większość wsi przewinęła się przez ten czas przez dom zmarłego. Każdy, kto miał chęć, mógł przyjść w dogodnej dla siebie godzinie i pożegnać zmarłego. Rano większość ludzi rozchodziła się do swoich obowiązków w gospodarstwie.

Wraz z przemieszczaniem się ludności po drugiej wojnie światowej pogrzeby w nowych miejscach zamieszkania stały się okazją do podtrzymywania więzów rodzinnych. Odnotowano zjawisko bardzo częstych przyjazdów rodziny mieszkającej w innych częściach Polski na pogrzeb osoby z rodziny. W takiej sytuacji, np. przyjazdu bliskiej rodziny z dość odległych stron, chociażby „z centrali na zachód” (przykładowo z okolic Kolbuszowej na Dolny Śląsk), należało przygotować poczęstunek i zapewnić ewentualny nocleg (r. 15, r. 30, r. 41).

Zwyczajem, który został wspomniany jako typowy tylko dla rodzin łemkowskich, było otwieranie wszystkich szaf i szuflad w mieszkaniu. Czynność tę należało wykonać przed wyniesieniem trumny z domu. Wierzono, że zmarły może wziąć te rzeczy, które chce i które są mu potrzebne do spokojnego odejścia (r. 45).

Rytuał pogrzebu na wsiach składał się z trzech stacji. Pierwsza to przyjazd księdza, modlitwa nad ciałem w domu. Rodzina po raz ostatni żegnała się ze zmarłym. Następnie zamykano wieko trumny i wyprowadzano zmarłego z domu. Najczęściej sąsiedzi wynosili trumnę na ramionach. Zmarłego zawsze kładziono skierowanego nogami do drzwi, tak go również wynoszono z domu na cmentarz. Wierzono, że „jeśli się tego nie przestrzega, to dusza zmarłego nie opuści domu"31.

31 H. Wesołowska, Zwyczaje i obrzędy rodzinne, [w:] Kultura ludowa śląskiej ludności rodzimej, red. D. Simonides, P. Kowalski, Oficyna Wydawnicza „Volumen”, Wrocław 1991, s. 256. 
Następnie konduktem, któremu przewodniczył ksiądz, szło się na piechotę do kościoła, który mógł być odległy nawet o kilkanaście kilometrów. W czasie pogrzebu śpiewano pieśni żałobne za zmarłych. Bardzo ważną rolę odgrywał kościelny lub organista, który intonował poszczególne pieśni. Po odprawionej mszy wszyscy udawali się na cmentarz, gdzie następowały ostatnie modlitwy oraz złożenie ciała w grobie. Do domu wracano na piechotę. Po pogrzebie nie było stypy, tylko poczęstunek dla rodziny z dalszych stron. Społecznej ocenie podlegało to, jak rodzina zmarłego się „zaprezentuje”, kto przyjdzie lub nie przyjdzie na pogrzeb oraz na cmentarz, jak się będzie zachowywał (r. 38, r. 39, r. 44).

Cechą wyróżniającą społeczności wiejskich Dolnego Śląska jest różnorodność regionów, z których przybyli tam osadnicy po drugiej wojnie światowej. Wśród badanych posiadających przodków urodzonych na Kresach co czwarty (25\%) to mieszkaniec województwa dolnośląskiego ${ }^{32}$. Zadano pytanie o posiadanie krewnych w linii prostej, tj. rodzica, dziadka lub pradziadka. Biorąc pod uwagę błąd oszacowania próby było to około miliona obecnych mieszkańców Dolnego Śląska. Granica funkcjonowania pamięci komunikatywnej, dla której istotne jest przekazywanie doświadczeń z pokolenia na pokolenie, dotyczy trzech pokoleń wstecz ${ }^{33}$. W wywiadach pojawiały się informacje, że jeśli odbywa się pogrzeb osoby pochodzącej ze wschodu, to na taki pogrzeb przychodziły i nadal przychodzą „nieprzebrane tłumy” (r. 3), „ludzie ci czują się wspólnotowo zjednoczeni” (r. 29). Często można było nie znać danej osoby, ale ta kwestia miała znaczenie drugorzędne w sytuacji, kiedy osoba ta pochodziła z rodziny ze wschodu, „taj to swój, to nasz" (r. 42). Oprócz bardzo dużej frekwencji na pogrzebach nie sygnalizowano różnic w samych rytuale, pieśniach czy modlitwach.

Analizując współistnienie rodzin z różnych regionów w jednej wsi, respondentka mówi (r. 3):

W naszej wsi mamy taki miks, najwięcej rodzin z Polski Centralnej, rzeszowskie, tarnowskie, jest część wsi zasiedlona przez repatriantów ze Wschodu i kilka rodzin łemkowskich. Na początku to nawet jeździli do swojego kościoła we Wrocławiu, ale ponieważ wszyscy ich wytykali od odmieńców, to w końcu zaczęli chodzić do naszego kościoła, tylko że świętują dwa razy, nasze święta i swoje. Gdzie ktoś w latach sześćdziesiątych słyszał o ekumenizmie? Wszyscy wiedzieli skąd są, że akcja Wisła, i naprawdę mieli na początku na wsi ciężko.

32 CBOS BS/50/2012, Kresowe korzenie Polaków, Warszawa, s. 3.

33 J. Assmann, Pamięć kulturowa. Pismo, zapamiętywanie i polityczna tożsamość w cywilizacjach starożytnych, Wydawnictwo Uniwersytetu Warszawskiego, Warszawa 2008. 
Podtrzymywanie dziedzictwa kulturowego kresów wschodnich przestało być obecne jedynie w pamięci komunikatywnej, ale stało się elementem pamięci kulturowej wspólnej dla części mieszkańców całego Dolnego Śląska. Istnieje szereg instytucji powołanych do tego, aby tę pamięć kultywować, np. Ossolineum czy Towarzystwo Miłośników Kresów Wschodnich. Wydaje się, że podtrzymywanie pamięci o Łemkach ma zdecydowanie mniejszy zasięg.

Analizując różnice regionalne pomiędzy mieszkańcami obszarów wiejskich, należy odnotować ujednolicającą rolę Kościoła katolickiego jako ważnej instytucji nowo tworzących się społeczności lokalnych.

$\mathrm{Na}$ podstawie przeprowadzonych wywiadów można stwierdzić, że umierania i śmierci w społecznościach wiejskich Dolnego Śląska w latach powojennych nie tabuizowano. Stanowiły one realny element ludzkiego życia, dlatego możemy mówić, że w tradycyjnej społeczności wiejskiej mieliśmy do czynienia z modelem śmierci oswojonej ${ }^{34}$. Starano się, aby umierający, o ile nie uczynił tego wcześniej, pogodził się z Bogiem i ludźmi. Należało również wykonać wszelkie czynności, zabiegi, aby zapewnić mu możliwie godną, dobrą śmierć, a następnie by uchronić bliskich i rodzinę od ewentualnego niebezpieczeństwa związanego ze śmiercią jednego z członków rodziny i wsi. Wszystkie te poglądy i zachowania świadczą o tym, że mieszkańcy wierzyli w życie po śmierci, a także byli przekonani, że świat nadprzyrodzony przenika w pewien sposób naszą doczesność.

\section{POGRZEBY W SPOŁECZNOŚCIACH WIEJSKICH DZISIAJ}

Bardzo zmieniły się zachowania, jakie panują obecnie, w porównaniu z tymi, jakie obowiązywały mieszańców wsi tuż po wojnie. W tej części chciałabym krótko przedstawić, na podstawie wypowiedzi młodszego pokolenia, jak wyglądają współczesne pogrzeby w społecznościach wiejskich. Obecnie nie są już organizowane pogrzeby trzyczęściowe, z uwzględnieniem dużej roli rodziny i społeczności lokalnej. Organizacją pogrzebu najczęściej zajmuje się firma, podkreśla się wygodę takiego rozwiązania (r. 62, r. 74, r. 90). Skróceniu uległ cały rytuał „świat jest szybki, więc i pogrzeby są szybkie” (r. 65). Doskonały przykład szybkiego pogrzebu referuje respondentka (r. 84):

$34 \quad$ P. Ariès, Człowiek i śmierć, PWN, Warszawa 1989. 
Doszliśmy do jakiegoś ekstremum, ostatnio byłam na pogrzebie we Wrocławiu, zmarła szkolna koleżanka mamy, to była fabryka pogrzebowa, jeden pogrzeb się nie skończył, a żałobnicy z drugiego czekają na wejście do kaplicy na cmentarzu. Zamieszanie z wejściem, z wyjściem. Całość ze złożeniem urny w katakumbarium trwała 40 minut. Najbardziej byłam zaskoczona, że księdzu brakło komunikantów w czasie komunii, chyba był zaskoczony liczbą osób na Mszy, Pani wprawdzie od lat mieszkała we Wrocławiu, ale pochodziła z małej wioski pod Wrocławiem, wiele osób, które ją pamiętało przyjechało i klops... Niektóre moje starsze sąsiadki były mocno zszokowane, ani różańca przed, ani się pożegnać...

Jak zauważa inna respondentka, teraz to jest „trochę płytki taki pogrzeb, w porównaniu do tego, co mi mówiła babcia, jest znacząca różnica pomiędzy tym, co obecnie jest realizowane w stosunku do tego, czego doświadczyli nasi dziadkowie” (r. 87). Zauważalny jest brak przestrzeni do wyrażania swoich uczuć. Bardzo często w wypowiedziach pojawia się zdanie, że na pogrzebach wiejskich i tak poświęca się więcej czasu na godne pożegnanie zmarłego niż ma w mieście (r. 63, r. 78, r. 90).

W przypadku, kiedy osoba umiera w domu, dzwoni się po lekarza, aby wypisał akt zgonu. Zgodnie z przepisami ciało zmarłej osoby powinno pozostać w domu dwie godziny. Po tym czasie przyjeżdża firma pogrzebowa i zabiera ciało do swojej chłodni. Decydując się na usługi firmy, rodzina może zlecić jej załatwienie wszystkich formalności.

W dniu samego pogrzebu, pokrywając stosunkowo wysokie koszty transportu, można przywieźć trumnę do Kościoła na godzinę przed Mszą (co na obszarach wiejskich nie jest często praktykowane). Jest to czas na pożegnanie i wspólną modlitwę przed nabożeństwem. W przypadku, kiedy rodziny nie jest na to stać lub nie chce sprowadzać trumny do Kościoła, odbywa się Msza w intencji zmarłego, następnie nabożeństwo w kaplicy cmentarnej i ostatnie modlitwy nad grobem. Warto dodać, że niektóre osoby starają się wywrzeć na rodzinie presję, aby trumna była obecna w kościele w czasie pogrzebu (r. 73, r. 81).

Społecznej ocenie poddaje się liczbę osób, które są obecne na pogrzebie. Jeśli tych osób jest dużo, to znaczy że zmarły cieszył się szacunkiem w społeczności lokalnej. Sam przebieg pogrzebu w dużym stopniu zależy od możliwości finansowych rodziny (np. czy będzie obecny organista lub inna oprawa muzyczna, czy zapewniony zostanie autobus, którym chętni będą mogli przejechać z kościoła na cmentarz - w miejscowościach, gdzie cmentarza nie ma [r. 47, r. 37]).

Bardzo często firmy w ramach zasiłku pogrzebowego (wypłacanego z ZUS-u lub KRUS-u) oferują możliwość zorganizowania stypy. Spotkania takie są coraz częściej 
organizowane w świetlicach wiejskich, salach bądź restauracjach. Następuje pewne przesunięcie akcentów. W opowieściach seniorów nie akcentowano aż tak bardzo kwestii związanych z przygotowaniem poczęstunku po pogrzebie. Współcześnie organizuje się nawet „wielkie stypy, często zakrapianie” (r. 89). Celem nadrzędnym takich spotkań niekoniecznie jest wspominanie nieboszczyka czy refleksja nad własną przemijalnością, ale wymiana informacji nt. zmian, jakie zaszły w życiu osób, które dawno się nie widziały (r. 52, r. 74, r. 95).

Stypa obecnie bywa najdłuższym, często wielogodzinnym, elementem kończącym dzień pogrzebu. Takie zmiany spotykają się często z dezaprobatą respondentów starszych. Panująca atmosfera już na pogrzebie, w pochodzie na cmentarzu, a następnie na stypie bliższa jest plotkowaniu niż wspominaniu zmarłego. „Najbliżsi to przeżywają, ale reszta oddala te myśli i przychodzi sobie porozmawiać o różnych sprawach" (r. 61).

\section{PODSUMOWANIE}

Obrzędy przejścia zawsze spełniały liczne funkcje w życiu społeczności wiejskich, obecnie można stwierdzić, że funkcje te uległy znacznej redukcji. Śmierć kogoś bliskiego staje się rodzajem sprawdzianu dla rodziny - jak się zachowa, które zwyczaje zostaną zachowane. Zaangażowanie reszty społeczności lokalnej w rytuał pogrzebu ogranicza się najczęściej do obecności na nabożeństwie.

Liczba i różnorodność wymienianych rytuałów związanych z pogrzebem zależała od wieku respondentów. Najstarsi z nich długo i obszernie wyjaśniali, dlaczego podejmowano takie, a nie inne zachowania, które obecnie już nie są praktykowane. Przebieg pogrzebu w czasach dawniejszych zależał od wieku zmarłego (dziecko, osoba młoda), płci, rodzaju śmierci, pozycji, jaką zajmował we wspólnocie rodzinnej oraz społeczności lokalnej.

Do lat osiemdziesiątych na wsi dolnośląskiej odbywały się trójetapowe pogrzeby ze stacją w domu zmarłego, w kościele i na cmentarzu. Obecnie pogrzeb ogranicza się do mszy w kościele oraz nabożeństwa na cmentarzu. Została ograniczona do minimum uroczystość samego pogrzebu, choć podkreśla się, że na wsi i tak czas poświęcony na nabożeństwo pogrzebowe jest dłuższy niż w mieście. Jednocześnie pogrzeby odbywają się w coraz bardziej kameralnych warunkach, coraz mniej czasu poświęca się na modlitwę 
przy zmarłym. Dobry pogrzeb to taki, na którym jest wiele osób. Jest to pewnego rodzaju wskaźnik szacunku, jakim dana osoba cieszyła się w społeczności, innym czynnikiem są możliwości finansowe rodziny.

Częścią rytuału, która zyskała na znaczeniu w ciągu ostatnich lat, jest stypa. Zjawisko to nie zyskuje pełnej akceptacji, szczególnie u seniorek i seniorów. Wskazuje się na przesunięcie akcentów, zamiast troski o godne pochowanie i pożegnanie nieboszczyka rodzina zajmuje się przygotowaniem stypy.

Zmiany związane z przeżywaniem śmierci i przebiegiem rytuału pogrzebowego są związane z medykalizacją życia, praktyki podtrzymujące zdrowie powierza się podmiotom zewnętrznym. Umieranie było sprawą prywatną, obecnie dominuje praktyka umierania szpitalnego. Rodzina, sąsiedzi, społeczność wsi kiedyś była w znacznie większym stopniu zaangażowana w cały proces chorowania i umierania, dziś najczęściej tylko „odwiedza się chorego w szpitalu”.

Pogrzeb nie jest, jak kiedyś, wydarzeniem dla całej społeczności lokalnej czy przynajmniej znacznej jej części, ale głównie dla rodziny. Zanikają czynności, które wcześniej były przypisane członkom rodziny, sąsiadom, takie jak przygotowanie zmarłego do pochówku czy organizacja poczęstunku. Rodzina została odciążona z obowiązku organizacji pogrzebu, zadania te przejęły firmy pogrzebowe. Coraz więcej mieszkańców wsi ma pozarolnicze źródła dochodu i nie może lub nie chce brać udziału w pogrzebach swoich sąsiadów.

Uległa redukcji obrzędowość związana ze śmiercią i pogrzebem mieszkańców wsi, jednocześnie na podstawie literatury i badań własnych daje się dostrzec wyraźnie większe zainteresowanie wyglądem i troską o groby najbliższych, niż w czasach przedwojennych ${ }^{35}$.

Pomimo wszystkich zmian, które w skrótowy sposób starałam się przedstawić, rytuały pogrzebu nadal są jednymi z najsilniejszych elementów socjalizujących, budujących tożsamość społeczną ich uczestników.

\footnotetext{
35 J. Kolubszewski, Cmentarze, Wydawnictwo Dolnośląskie, Wrocław 1996; B. Szczepańska, Cmentarze wczoraj i dziś. Zmiany $w$ funkcjonowaniu cmentarzy $w$ opiniach trzech pokoleń mieszkańców wsi polskiej (na przykładzie Smardzowa), „Forum Socjologiczne" 2017, nr 8, s. 253-270.
} 


\section{BIBLIOGRAFIA}

Aries P., Człowiek i śmierć, PWN, Warszawa 1989.

Aries P., Pięć wariacji na cztery tematy, tłum. S. Cichowicz, J. M. Godzimirski, [w:] Antropologia śmierci. Myśl francuska. Wybór S. Cichowicz, J. M. Godzimirski, PWN, Warszawa 1993.

Assmann J., Pamięć kulturowa. Pismo, zapamiętywanie i polityczna tożsamość w cywilizacjach starożytnych, Wydawnictwo Uniwersytetu Warszawskiego, Warszawa 2008.

Baniak J., Istota, funkcje i ewolucja rytuału religijnego, „Studia Socjologiczne” 1992, nr 1.

Berger P. L., Luckmann T., Społeczne tworzenie rzeczywistości, tłum. J. Niżnik, PIW, Warszawa 1983.

Burszta W. J., Antropologia kultury. Tematy, teorie, interpretacje, Wydawnictwo Zysk i S-ka, Poznań 1998.

Bystroń J. S., Dzieje obyczajów w dawnej Polsce, t. 2, PIW, Warszawa 1994.

CBOS BS/50/2012, Kresowe korzenie Polaków, Warszawa, s. 3.

Durkheim É., Elementarne formy życia religijnego. System totemiczny w Australii, tłum. A. Zadrożyńska, PWN, Warszawa 1990.

Helling I., Metoda badań biograficznych, [w:] Metoda biograficzna w socjologii, red. J. Włodarek, M. Ziółkowski, PWN, Warszawa 1990.

Jakitowicz M., Ludowe opowieści o oszukanej śmierci jako symptom „oswajania” zjawiska, [w:] Problemy wspótczesnej tanatologii, red. J. Kolbuszewski, t. 1, Wrocławskie Towarzystwo Naukowe, Wrocław 1997.

Kolbuszewski J., Cmentarze, Wydawnictwo Dolnośląskie, Wrocław 1996.

Mariański J., Śmierć i umieranie w ujęciu socjologicznym w nawiązaniu do myśli Jana Szczepańskiego, [w:] W kręgu myśli Profesora Jana Szczepańskiego, red. D. Kadłubiec, E. Ogrodzka-Mazur, A. Kasperek, t. 3, Wydawnictwo ARKA, Cieszyn 2017.

Ostrowska A., Śmierć w doświadczeniu jednostki i społeczeństwa, Wydawnictwo IFiS PAN, Warszawa 2005.

Przybyłowska I., Wywiad swobodny ze standaryzowaną listą poszukiwanych informacji i możliwości jego zastosowania w badaniach socjologicznych, „Przegląd Socjologiczny” 1978, t. 20.

Rosiński F., Śmierć w polskiej tradycji ludowej, [w:] Problemy współczesnej tanatologii, red. J. Kolbuszewski, t. 3, Wrocławskie Towarzystwo Naukowe, Wrocław 1999.

Stanny M., Przestrzenne zróżnicowanie rozwoju obszarów wiejskich w Polsce, IRWiR PAN, Warszawa 2013.

Stomma L., Antropologia kultury w Polsce - dziedzictwo, pojęcia, inspiracje, materiały do słownika, cz. III, „Polska Sztuka Ludowa” 1981, R. 35, nr 1.

Szczepańska B., Cmentarze wczoraj i dziś. Zmiany w funkcjonowaniu cmentarzy w opiniach trzech pokoleń mieszkańców wsi polskiej (na przykładzie Smardzowa), „Forum Socjologiczne” 2017, nr 8.

Szczepański J., Elementarne pojęcia socjologii, PWN, Warszawa 1970.

Szczepański J., Sprawy ludzkie, Czytelnik, Warszawa 1980.

Turek K., Ludowe zwyczaje, obrzędy i pieśni pogrzebowe na Górnym Śląsku, Wyd. Uniwersytetu Śląskiego, Katowice 1993.

Wańczowski M., Księga żałoby i śmierci, nakł. autora, Opole 1993.

Wesołowska H., Zwyczaje i obrzędy rodzinne, [w:] Kultura ludowa śląskiej ludności rodzimej, red. D. Simonides, P. Kowalski, Oficyna Wydawnicza „Volumen”, Wrocław 1991.

Znaniecki F., Socjologia wychowania. Urabianie osoby wychowanka, t. 2, Naukowe Towarzystwo Pedagogiczne, Lwów 1930.

Żygulski K., Przemiany obyczajowe a kultura masowa, [w:] Nowe obyczaje i obrzędy, red. E. Ciupak, M. Czerwiński, J. K. Makulski, K. Żygulski, Młodzieżowa Agencja Wydawnicza, Warszawa 1977. 